\title{
An overview of the Hymenoptera Chrysididae from humid urban zones near Abu Dhabi (UAE)
}

\author{
Franco Strumia' \& Antonius van Harten² \\ 'Physics Department, Pisa University, Largo Pontecorvo 3, 56127 Pisa, Italy; e-mail: franco.strumia@unipi.it \\ ${ }^{2}$ Almada, Portugal; e-mail: tonyvanharten@gmail.com
}

\begin{abstract}
The Chrysididae Hymenoptera of the Abu Dhabi territory has ben studied by means of Malaise Traps. The comparison between humid and dry zones reveals the richer biodiversity preserved even in small humid zones. Two new species are discovered and described, namely: Hedychridium caerulescens n. sp. and Chrysis houbaraeensis n. sp. In the humid zones the uncommon Adelopyga huberi Kimsey, 1988 is discovered and illustrated.
\end{abstract}

KEY WORDS Chrysididae; cuckoo wasp; United Arab Emirates; Abu Dhabi; humid zones.

Received 28.06.2020; accepted 18.08.2020; published online 06.11.2020

\section{INTRODUCTION}

Abu Dhabi (UAE) is the westernmost town of the United Arab Emirates (UAE). Located along the flat and sandy shores on the Persian Gulf, it is surrounded by seawater and marshes. Humid zones near Abu Dhabi were recently established as nature reserves to protect the unique biodiversity.

Recently we have investigated the effects of humid zones on the insect's biodiversity (Strumia et al., 2017). Similar results were also observed in Arabia: Oman, Dophar Province (F. Strumia unpublished data). The availability of permanent water around all the year allows the presence of a local rich and diversified insects population, especially in a dry land.

The largest species number was observed in the most studied humid sites confirming the result recently observed in the Mediterranean region (Strumia el al., 2017).

\section{MATERIAL AND METHODS}

Insects were captured in two nature reserves near Abu Dhabi (UAE) by using Malaise traps, namely:

1 - "Al Wathba Wetland Reserve". The trap was operated by A. Saji \& A. van Harten and captured from February 2015 up to April 2017. Al Wathba Wetland Reserve, with a surface of about 4.9 square $\mathrm{km}$, is a complex of permanent surface water bodies, both natural and man made, at about $40 \mathrm{~km}$ south-east of central Abu Dhabi. Al Wathba was established as a nature reserve in 1998. The soil is mainly dry and sandy, thus favorable to the nesting of several Hymenoptera species (Figs. 1, 2).

2 - "Houbara Protected Area": A. Saji \& A. van Harten operated a Malaise trap. Insects were captured in this reserve from November 2015 up to April 2017.

Houbara Protected Area is located in the Al Dafra region, south of road E11 with a surface of about 770 square $\mathrm{km}$. The reserve consists of a costal plain of dry sandy ground and gravel terrains (Fig. 3). The proximity to the Persian Gulf coast 
provides some humidity. Houbara Protected Area was established in 2014.

While "Al Wathba Wetland Reserve" is a truly humid site inside the urban area, the "Houbara Protected Area" is located about $120 \mathrm{~km}$ west of the Abu Dhabi town and along the Persian Gulf coast. Houbara appears to be a standard dry biotope in Arabian Desert. Thus it is possible to perform a comparison with the material captured in the humid "Al Wathba Wetland Reserve".

A few additional Chrysididae (about $12 \%$ of the total) were randomly captured around Abu Dhabi during this investigation, mainly in dry sites Southeast of town (Fig. 4).

These specimens are represented by common species widely distributed into Arabian Peninsula and typical of the Near East Chrysididae fauna (Strumia \& Dawah, 2008; Strumia, 2014). Surprisingly, three Hedychridium resulted to belong to a new species. Body shape and color differ from all other Near East Hedychridium. This novelty is worth to be described here.

\section{RESULTS}

In the above two Protected Areas between 2015 and 2017 the Malaise traps captured about $131 \mathrm{Hy}-$ menoptera Chrysididae individuals, that resulted to belong to 22 species and nine genera, as listed below (Table 1).

\section{Systematics}

Ordo HYMENOPTERA Linnaeus, 1758

Superfamilia CHRYSIDOIDEA Latreille, 1802

Familia CHRYSIDIDAE Latreille, 1802

Subfamilia CHRYSIDINAE Latreille, 1802

Genus Adelopyga Kimsey, 1988

Adelopyga huberi Kimsey, 1988

Material STUdied. Houbara Protected Area, 01-30.05.2016, 1 female, Malaise trap.

Distribution. Oman (Whaiba sands, Kimsey, 1988). New record for UAE.

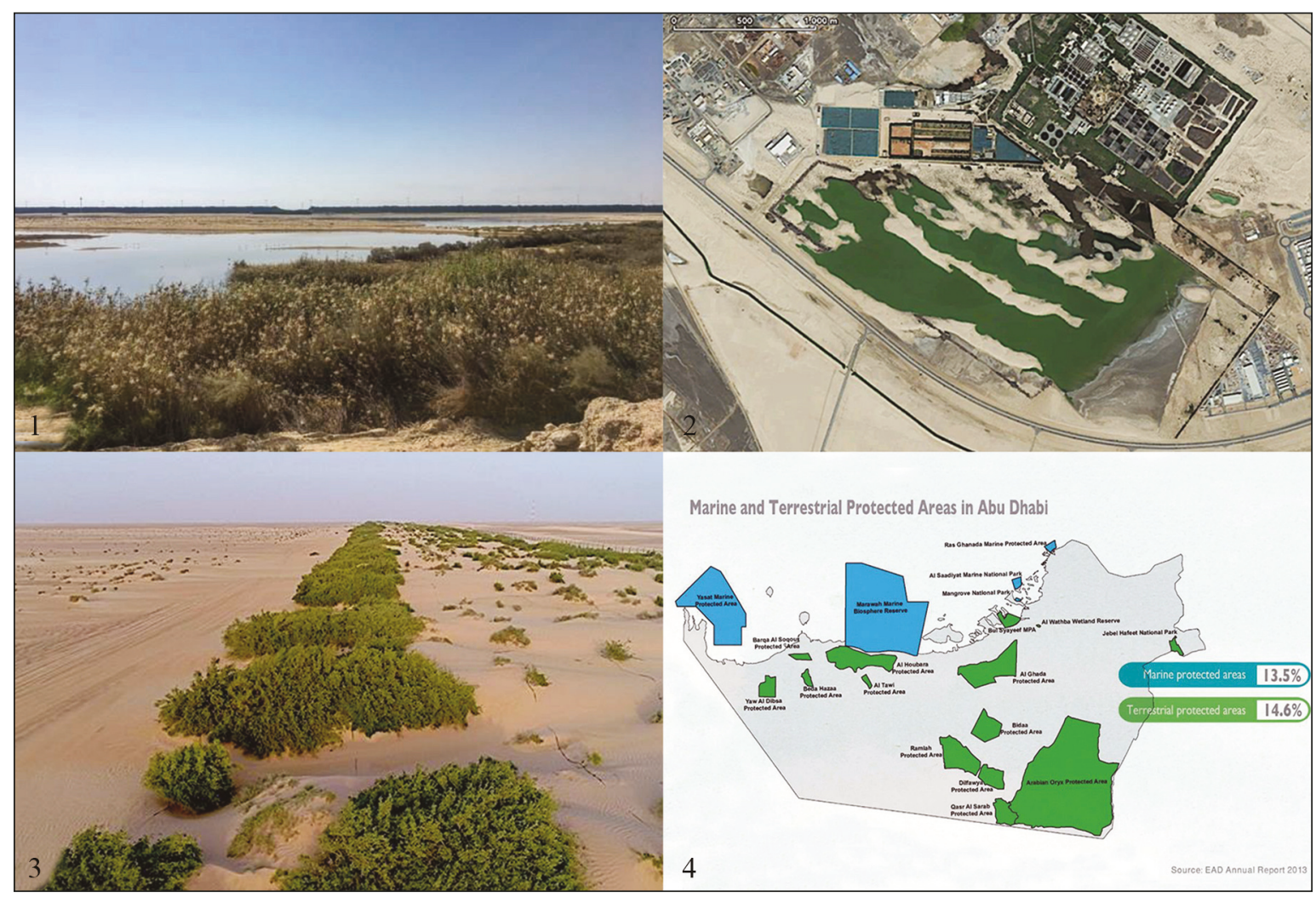

Figure 1. View of Al Wathba Wetland Reserve, Abu Dhabi. Figure 2. Aerial view of the Al Wathba Wetland Reserve, Abu Dhabi. Figure 3. Overview of the Houbara Protected Area. Figure 4. Distribution of the protected areas around Abu Dhabi. 


\begin{tabular}{|c|c|c|c|c|}
\hline $\mathbf{N}^{\circ}$ & Species observed & Al Wathba & Houbara & $\begin{array}{c}\text { Near Abu } \\
\text { Dhabi }\end{array}$ \\
\hline 1 & Adelopyga huberi Kimsey, 1988 & & \# & \\
\hline 2 & Cephaloparnops denticulatus Spinola, 1838 & & \# & \\
\hline 3 & Chrysis blanchardi Lucas, 1849 & \# & & Al Bida'a \\
\hline 4 & Chrysis houbarensis n. sp. & & \# & \\
\hline 5 & Chrysis jousseaumei Buysson, 1897 & \# & \# & \\
\hline 6 & Chrysis laeta Dahlbom, 1854 & \# & & \\
\hline 7 & Chrysis palliditarsis Spinola, 1838 & \# & $\#$ & \\
\hline 8 & Chrysis viridissima Klug, 1845 & \# & $\#$ & Al Bida'a \\
\hline 9 & Hedychridium aegyptiacum Du Buysson, 1898 & \# & & Al Bida'a \\
\hline 10 & Hedychridium aequabilitum Linsenmaier, 1994 & \# & & \\
\hline 11 & Hedychridium anithae Strumia, 2014 & \# & \# & Al Bida'a \\
\hline 12 & Hedychridium caerulescens $\mathrm{n}$. $\mathrm{sp}$. & & & Al Tawi \\
\hline 13 & Hedychridium disiunctum Linsenmaier, 1994 & & $\#$ & \\
\hline 14 & Hedychridium holopygum Linsenmaier, 1994 & \# & & \\
\hline 15 & Hedychridium iridirufum Linsenmaier, 1994 & \# & $\#$ & Al Tawi \\
\hline 16 & Hedychridium planifrons Du Buysson, 1900 & \# & & \\
\hline 17 & Hedychrum alfierii Trautmann 1926 & & $\#$ & \\
\hline 18 & Holopyga beaumonti Balthasar, 1953 & $\#$ & & \\
\hline 19 & Holopyga subglabrata Linsenmaier, 1994 & $\#$ & & \\
\hline 20 & Holopyga vicissituda Linsenmaier, 1994 & $\#$ & & \\
\hline 21 & Omalus margianus (Semenov, 1932) & \# & \# & \\
\hline 22 & Platycelia ehrenbergi Dahlbom, 1845 & \# & & \\
\hline 23 & Spintharina dubai Bohart, 1987 & \# & & \\
\hline \multirow[t]{2}{*}{24} & Spintharina integerrima Klug, 1845 & & & Al Ramlah \\
\hline & $\mathrm{N}^{0}$ of species & 17 & 11 & 7 \\
\hline
\end{tabular}

Table I. Checklist of Chrysididae species observed near Abu Dhabi reserves in 2015-2018.

REMARKs. Adelopyga was described as a highly modified genus of Elampini (Chrysididae). Until now $A$. huberi was known from two females from south Oman. This second find confirms its presence in western Arabian Peninsula. The holotype has: "abdominal sterna flat or shallowly convex ... It should be noted that the type and paratype specimens were preserved in alcohol and then critical point dried. The convexity of the abdominal sternum may be due to this treatment" (Kimsey, 1998: 334). It is worth to note that the specimen from Abu Dhabi has a concave sternum as usual of all the Chrysididae species (Fig. 5). Our find shows that "abdominal sterna flat or shallowly convex" is not a distinctive feature of Adelopyga genus.

Cephaloparnops Bishoff, 1910

Cephaloparnops denticulatus (Spinola 1838)

Material studied. Houbara Protected Area, 01-30.06.2016, 4 males, 3 females, same locality, 01-30.05.2016, 2 males, Malaise trap.

Distribution. Palaearctic, North Africa, Middle East. Iran (Kimsey \& Bohart, 1991). New record for UAE (Strumia, 2014). 


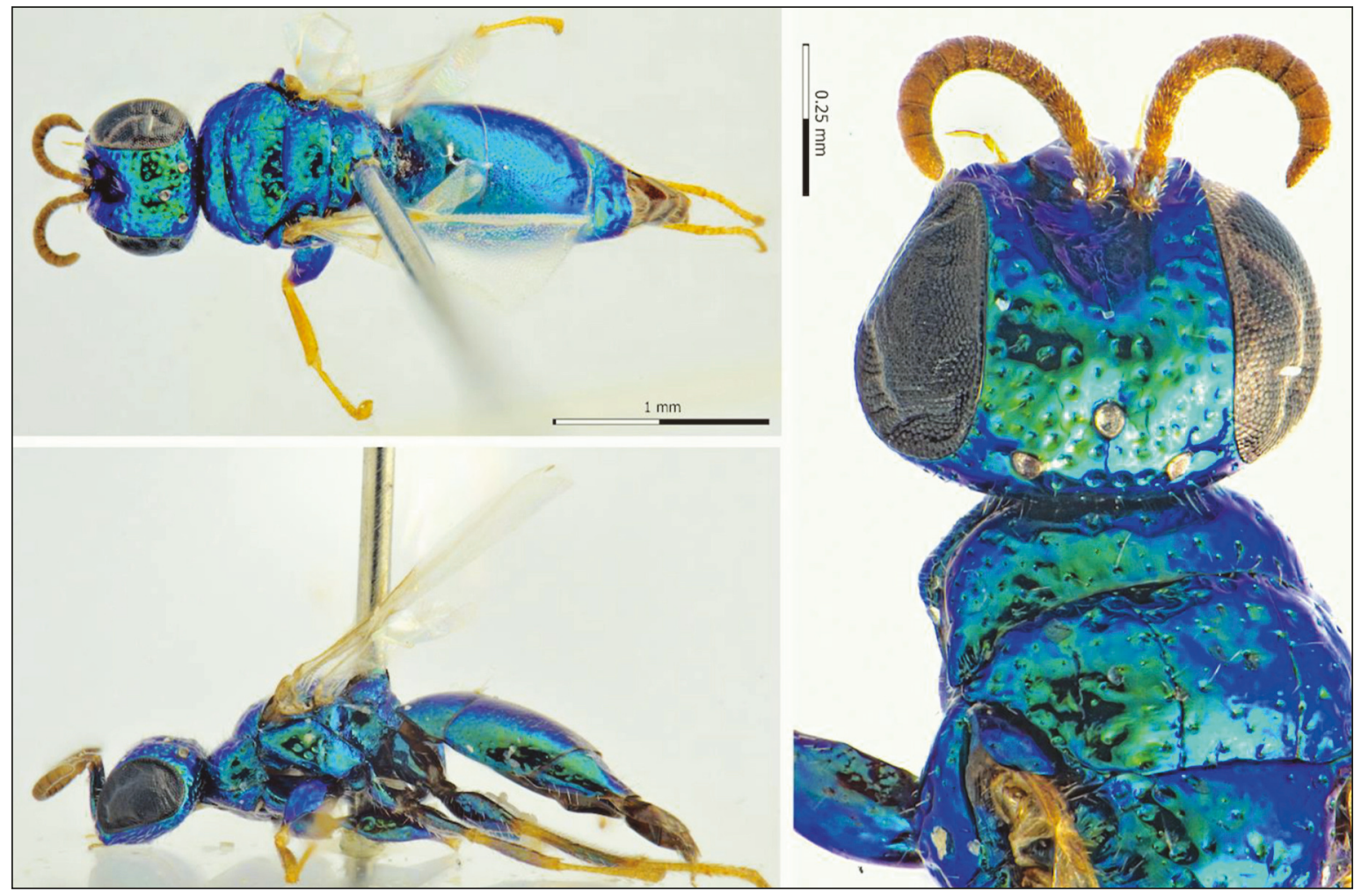

Figure 5. Female of Adelopyga huberi Kimsey, 1988; above: dorsal view; below: lateral view; right: head and dorsum.

Chrysis Linnaeus, 1761

\section{Chrysis blanchardi Lucas 1849}

EXAMINED MATERIAL. Al Wathba Wetland Reserve, 04.04.2017, 4 males; same locality, 20.04. 2017, 1 male, Malaise trap.

Distribution. North Africa, Spain, (Linsenmaier, 1999).

Chrysis houbaraeensis n. sp. Figs. 6-9 http://zoobank.org/urn:lsid:zoobank.org:act:7EF2 54F5-05E3-44A8-A28F-C3629CC1A617

DiAgnosis. The male entirely blue, the bicolor female, the shape of third Tergite, the head and pronotum trasverse, larger then longer, identify the new species.

EXAMINED MATERIAL. Holotype male: UAE, Abu Dhabi, Houbara Protected Area, 01-30.06.2016, Malaise trap, leg. A Saji \& van Harten. The holotype is preserved in the Natural History Museum of Pisa University. Paratypes: 1 male, same locality, 01-30.05.2016, Malaise trap, leg. A Saji \& A. van Harten; 1 male, same locality, 01.11-10.12.2015, Malaise trap, leg. A Saji \& A. van Harten; 1 female, same locality, 01-30.05.2016, Malaise trap, leg. A. Saji \& A. van Harten.

DesCRIPTION OF HOLOTYPE MALE. Body length: $\mathrm{L}=5.6 \mathrm{~mm}$. Body color: uniform blue in color.

Metasoma Sternum II is metallic blue with rounded well-separated black spots in contact with lateral border.

Head. Transverse, larger then longer: $\mathrm{L} / \mathrm{W}=$ 0.43 ; scapal basin with white decumbent setae (Figs. 5, 6); TFC strong with two backward arms surrounding the middle ocellus; malar space about 1 MOD long; clypeus in middle elevated with a black distal border; ocellocular angle obtuse; distance between lateral ocellus and compound eye larger than one MOD; mandible black, distally brown.

Mesosoma. Pronotum short, transverse with pointed anterior angles (Figs. 5, 6); punctures on head and pronotum deep, about 0.4 to $0.6 \mathrm{MOD}$ in 
diameter; punctures separation less then their diameter; a few very small (0.2 MOD or less) punctures between; punctures stronger and separated as much as their diameter (Figs. 5, 9) on mesonotum central part and scutellum; legs metallic green with tarsus non-metallic clear brown; mesopleuron punctures smaller than on Mesonotum; hairs white and short on all body; distal border of third tergite has a very thin transparent rim; tegula unusually small (1.7 MOD long) and metallic blue.

VARIABILITY. Body length: male paratype: $\mathrm{L}=6.0$ $\mathrm{mm}$ and $6.1 \mathrm{~mm}$ respectively. female paratype, $\mathrm{L}=$ $6.4 \mathrm{~mm}$. Males are uniform blue in color, the female paratype is bicolor: blue green body with mesonotum and scutellum red between punctures but with punctures bottom green (Fig. 9). Female has metasoma with strong red shining on disc of TII and TIII
(Fig. 7). Sexual dimorphism: the difference between males and the only one female available is mainly in the red color on Mesosoma and Metasoma.

Distribution. New record for UAE.

ETYMOLOGY. The species is named from the collecting site.

REMARKS. The new species belong to the $C$. pulchella species-group, as demonstrated by the male genitalia (Fig. 8) and the shape of third tergite (Figs. $6,7)$.

\section{Chrysis (Exachrysis) jousseaumei Buysson 1897}

EXAMINED MATERIAL. Houbara Protected Area, 01-30.05.2016, 3 females; same locality, 01-30. 06.2016, 2 females; same locality, 01-30.04.2016, 2

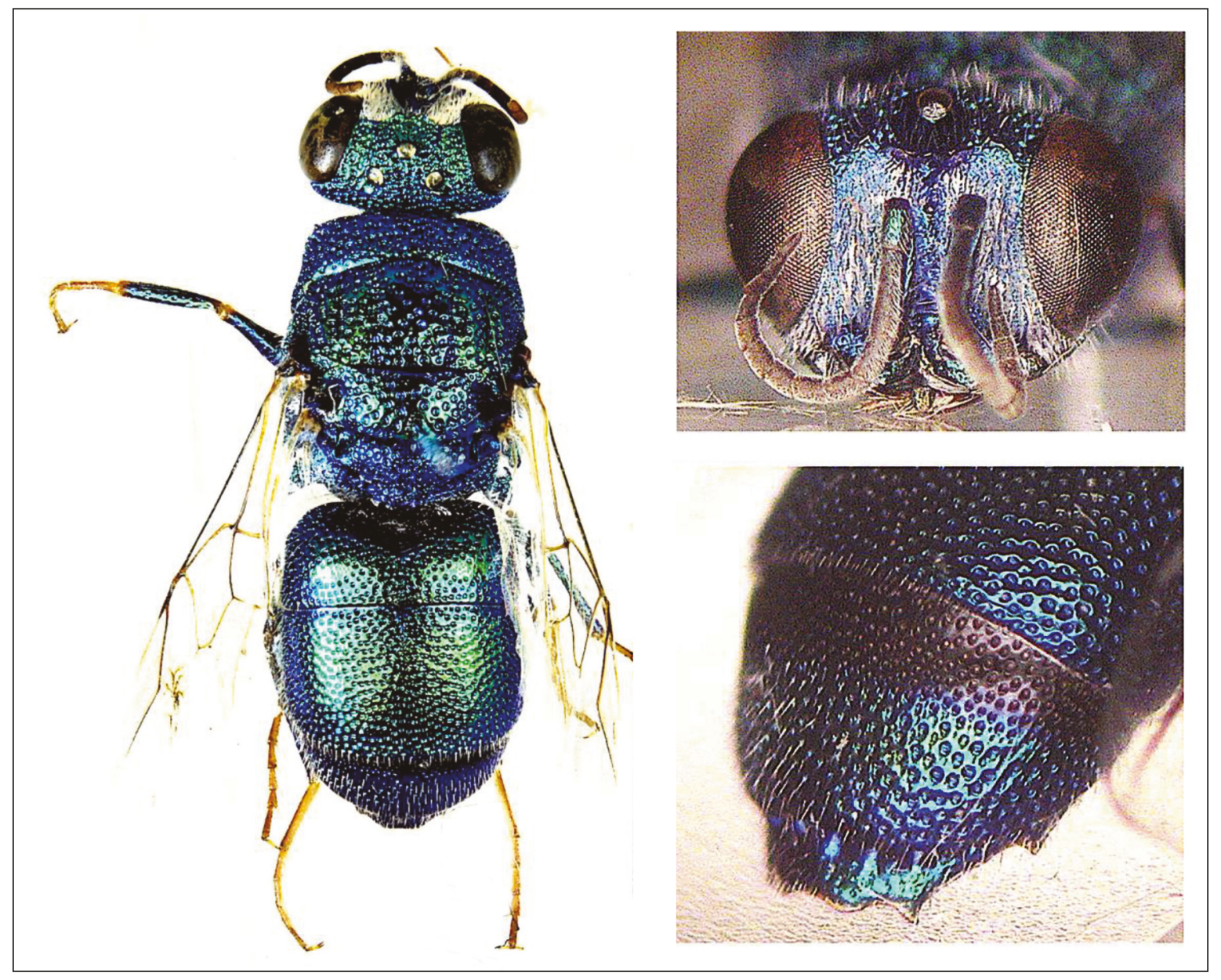

Figure 6. Male holotype of Chrysis houbaraeensis $\mathrm{n}$. sp. Mesonotum dorsal view, face in frontal view (right above), Metasoma distal border and Tergum 3 in top lateral view (right below). 


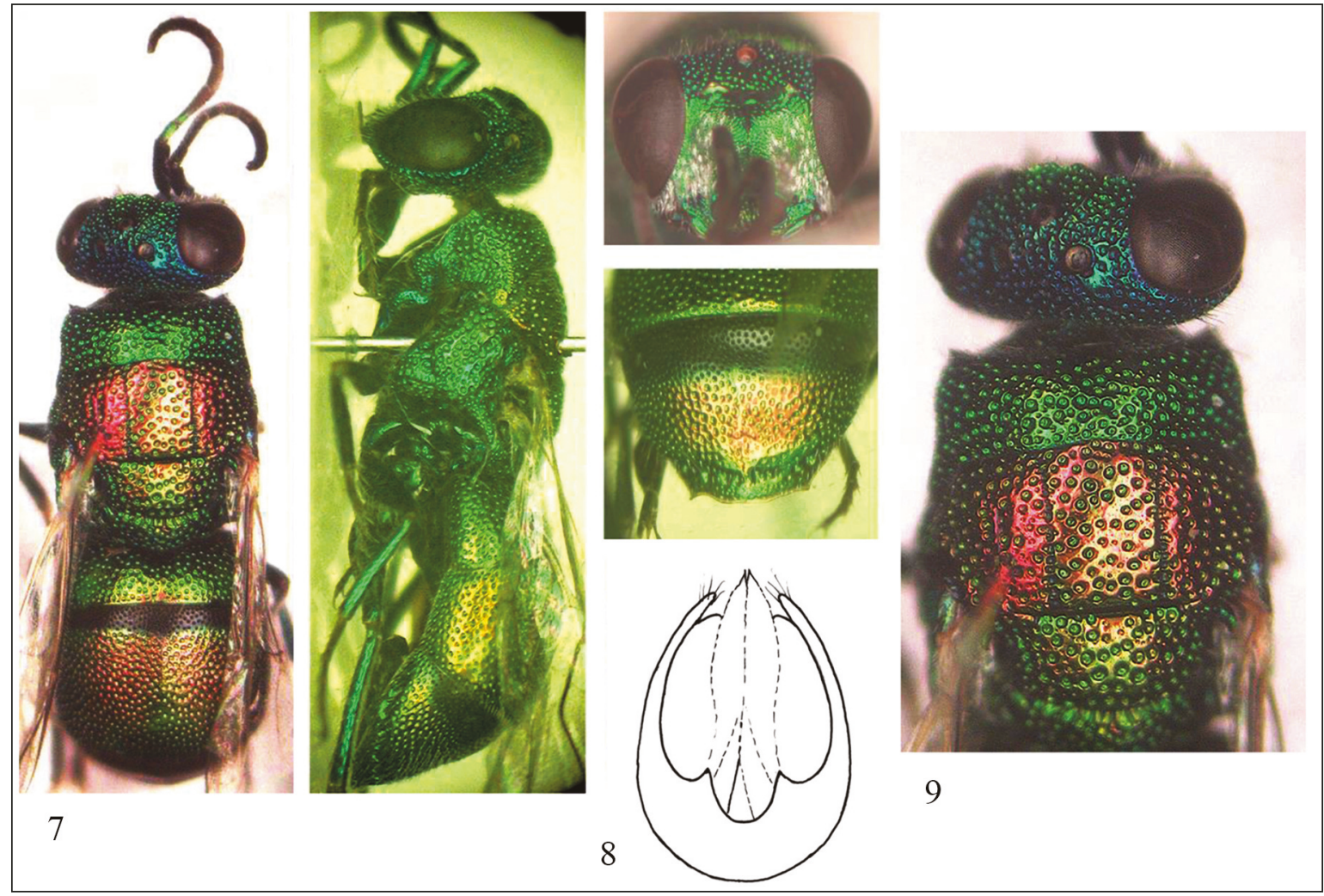

Figure 7. Female paratype of Chrysis houbaraeensis n. sp.; dorsum top view and lateral view; face, frontal view; metasoma Tergum 3 distal border. Figure 8. Outline of male genitalia of Chrysis houbaraeensis n. sp., holotype in the ventral view, length: $0.07 \mathrm{~mm}$. Figure 9. Detail of mesosoma dorsum of Chrysis houbaraeensis $\mathrm{n}$. sp. paratype female.

females; same locality, 1.11-10.12.2015, 1 female; same locality, 18.05.2017, 2 females. Al Wathba Wetland Reserve, 10.05.2017, 1 male.

Distribution. Northern half of Africa, Yemen, Somalia, UAE (Linsenmaier, 1994; Strumia, 2014).

\section{Chrysis laeta Dahlbom, 1854}

EXAMINED MATERIAL. Al Wathba Wetland Reserve, 01-28.02.2015, 1 female, Malaise trap.

Distribution. Algeria, Tunisia, Egypt, Oman, Yemen. UAE (Strumia, 2014).

\section{Chrysis palliditarsis Spinola, 1838}

EXAMINED MATERIAL. Al Wathba Wetland Reserve, 10.05.2017, 3 males, 1 female; Houbara Protected Area, 01.11-10.12.2015, 6 males; same locality, 01-30.04.2016, 1 male; Al Wathba Wetland Reserve, 01-31.03.2016, 5 males; same local- ity 19.09-31.10.2015, 3 males; same locality, 0131.01.2015, 1 male.

Distribution. North Africa: Egypt, Ethiopia, Eritrea, South Africa, Asia: Palestine, Oman, Iran, Saudi Arabia, Yemen, and U.A.E. (Linsenmaier, 1994). Chrysis palliditarsis is a widespread and common species of the South Palaearctic Region.

\section{Chrysis viridissima Klug, 1845}

EXAMINED MATERIAL. Al Wathba Wetland Reserve, 01-31.03.2015, 1 female; same locality, 0131.07.2015, 4 females; same locality, 01-28. 02.2015, 1 female; same locality, 19.09-31. 10.2015, 5 females; same locality, 04.04.2017, 2 females, 1 male; same locality, 10.05.2017, 1 female; Houbara Protected Area, 01-30.04.2016, 1 female; same locality, 01.11-10.12.2015, 1 female.

Distribution. Afrotropical Region. North Africa: Algeria, Egypt, Libya, Mauritania. Asia: 
India, Saudi Arabia, UAE, Oman, Iran, Turkey, Palestine (Linsenmaier, 1994; Madl \& Rosa, 2012).

Genus Hedychridium Abeille de Perrin, 1878

Hedychridium aegyptiacum Du Buysson, 1898

EXAMINED MATERIAL. Al Wathba Wetland Reserve, 01-31.01.2015, 2 males, 4 females; same locality, 01-28.02.2015, 2 males, 6 females; same locality, 01-31.03.2015, 2 males; same locality, 04.04.2017, 1 male. 2014).

Distribution. Egypt, Morocco, UAE (Strumia,

Hedychridium aequabilitum Linsenmaier, 1994

EXAMINED MATERIAL. Al Wathba Wetland Reserve, 01-28.02.2015, 2 males, 2 females; same locality, 01-31.01.2015, 3 males.

Distribution. Saudi Arabia, Oman, UAE (Linsenmaier, 1994; Strumia, 2014).

Hedychridium anithae Strumia, 2014 (= Hedychridium cyaneum Linsenmaier, 1999 ?). Fig. 10

EXAMINED MATERIAL. Al Wathba Wetland Reserve, 01-28.02.2015, 2 females; same locality, 0131.01.2015, 1 female; same locality, 01-31.03. 2015, 1 male, 1 female; Houbara Protected Area, 01-30.05.2016, 1 female.

Distribution. Iran, Southern-Africa, UAE and Tunisia (this last data is doubtful and need to be confirmed).

REMARK. Hedychridium anithae was described and illustrated in 2014 (Strumia 2014: 475, plates 11-14).

A paratype of $H$. anithae (also captured in Al Wathba Wetland Reserve) seems to be consistent with the description of Hedychrum cyaneum (Brullé, 1846) as proposed by Linsenmaier (1999). Hedychrum cyaneum was described by Brullé (1846) from South Africa, Cape of Good Hope. Unfortunately, the type of the species is probably lost and the generic placement is uncertain (Madl \& Rosa, 2012, Rosa \& Zai-fu Xu, 2015). In 1889, Radoszkowski described another species of Hedychrum with the same name [H. cyaneum] from Siberia, thus creating a primary homonymy. Kimsey \& Bohart (1991: p. 220) confirmed the placement of the Brullé species in the genus Hedychrum. Later, Linsenmaier (1999) assigns the Brullé species to the genus Hedychridium and briefly redescribes it, without specifying the specimens he studied, or if he was able to study the type. It is very likely that this was a personal interpretation of an old species, to which he put in synonym Hedychridium flavipes var. cyanomaculatum Trautmann, 1927. The latter species does not even belong to the genus Hedychridium, being, in reality, a Colpopyga flavipes flavipes (Eversmann, 1858) (Rosa, 2017), and this makes the proposal of Linsenmaier even more doubtful. In conclusion, for what was said previously, we do not deem that our specimens can be assigned to the supposed Hedychridium cyaneum Brullé. We therefore believe that Hedychridium anithae Strumia 2014 is a valid species and that

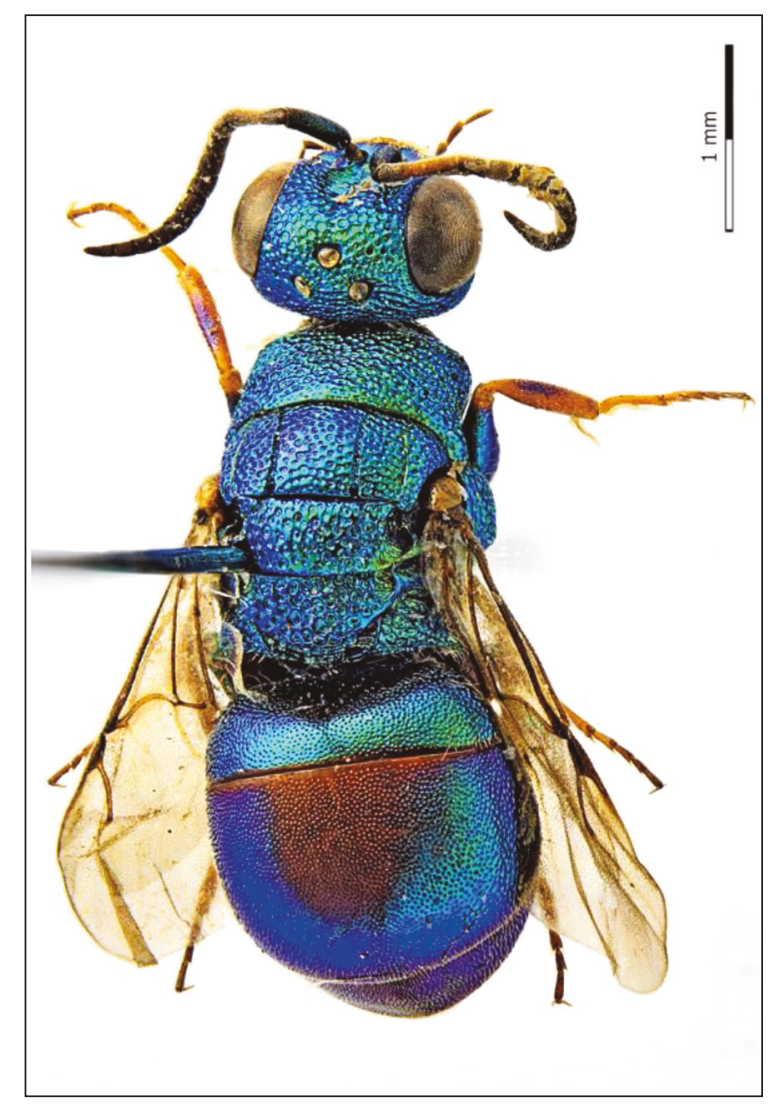

Figure 10. Dorsal view of Hedychridium anithae Strumia, 2014, male from Al Bida'a Protected area (Abu Dahbi), 20.07.2018. 
Hedychridium cyaneum as described by Linsenmaier (1999) is an inappropriate interpretation of an old description.

Hedychridium anithae is a frequent species in UAE and Iran (Kerman Province: Jiroft, KahnujTomgoran, Manoojan-Chermil 2017, males and females, leg. M. Purrezalai).

Hedychridium caerulescens n. sp. Figs. 11-13 http://zoobank.org/urn:lsid:zoobank.org:act:50521 1EA-4A15-4341-B56D-3D123B30B2AA

DiAGNOSIS. The metasoma color distribution, the non-metallic legs and the fine striation between punctures of mesopleuron (Fig. 13) easily identify the new species.

EXAMINED MATERIAL. Holotype female, UAE, Abu Dhabi, Al Tawi Protected Area, 19.09.2018, Malaise trap, leg. A. Saji \& A. van Harten. Al Tawi Protected Area. The holotype is preserved in the Natural History Museum of Pisa University. Paratype male: UAE, Abu Dhabi, Al Tawi Protected Area, 19.09.2018 Malaise trap, leg. A. Saji \& van Haten. Paratype female: Al Bida'a Protected Area, 29.10.2018, leg. A. van Harten.

DESCRIPTION OF THE HOLOTYPE FEMALE. Body length: $\mathrm{L}=3.9 \mathrm{~mm}$. Body color: head and mesosoma metallic blue-green; antenna scape dark brown with Flagellomeres F1 an F2 non-metallic brown. First tergite blue metallic, second also blue metallic, but with a large non metallic brown spot on disc; third tergite blue metallic only in the distal half (Fig. 11).

Head. Larger than longer in top view: $\mathrm{L} / \mathrm{W}=1.7$ Face transverse, scapal basin larger than higher, finely and horizontally striated in middle; mandible partially brown medially with an additional tooth on internal border; gena short, convergent, less than one MOD long; ocellocular angle obtuse; distance between hind acellus and compound eye larger than acellus diameter.

Mesosoma. Punctures on mesonotum relatively small and partially aligned transversally in the central part, larger on scutellum; mesopleuron rounded below with a very fine horizontal striation between the sparse punctures, (Fig.13); tegula small non metallic brown, as tybia and tarsus, femur blue metallic, hind tarsus first joint shorter than followings; antenna last joint long and pointed; wings radial cell close with a weakly sclerotized vein.
Metasoma. Terga punctures very fine and dense; third tergite blue metallic only in the distal half and with a thin transparent rim on distal border, less than 1 PD long, punctures even finer simple, a little larger distally. Metasoma underside brown with a weak blue spot on second sternite.

VARIABILITY. Body length. Male paratype, $\mathrm{L}=$ $4.1 \mathrm{~mm}$; female paratype $\mathrm{L}=3.9 \mathrm{~mm}$. Sexual dimorphism: minimal in body shape. Male paratype has the first metasoma tergite metallic blue. In female paratype this is non-metallic brown as tybia and tursus; female fore femur nonmetallic distally (Fig. 12); female third tergite weakly more pointed than male. Note that only three individuals are available for comparison.

ETymology. The name refers to the blue color of distal part of metasoma terga.

DisTRIBUTION. New record for UAE. The type locality of Al Tawi covers about 45 square $\mathrm{km}$ south of Houbara Protected Area and it is a desert dry zone.

REMARKS. In the revision of North-Africa Chrysididae, Linsenmaier (1999) proposed to split the genus Hedychridium in group of species. Among these, the roseum-sculpturatum group is well defined and easy to identify. According to Linsenmaier this group is unique by having the first joint of hind tarsus of reduced length, antenna strong and pointed, metasoma punctures fine, body hairs short and white. Several species show more or less nonmetallic metasoma terga and legs. Non-metallic metasoma terga were previously associated with species of the $H$. roseum group. The combination of the above features makes identification easy and unquestionable.

The roseum-sculpturatum group is species rich and need a new revision of the Palaearctic fauna, since past descriptions are poor and may refer to different taxa. We had recently the opportunity to study a large number of individuals of roseum-sculpturatum group from the Near East (Egypt, Palestine, Syria, Turkey, UAE, Arabia, Yemen and Iran) but none approach the present specimens from Abu Dhabi. It is thus worth to describe them as a new species.

Hedychridium disiunctum Linsenmaier, 1959

EXAMINED MATERIAL. Houbara Protected Area, 01-30.06.2016, 2 females. 


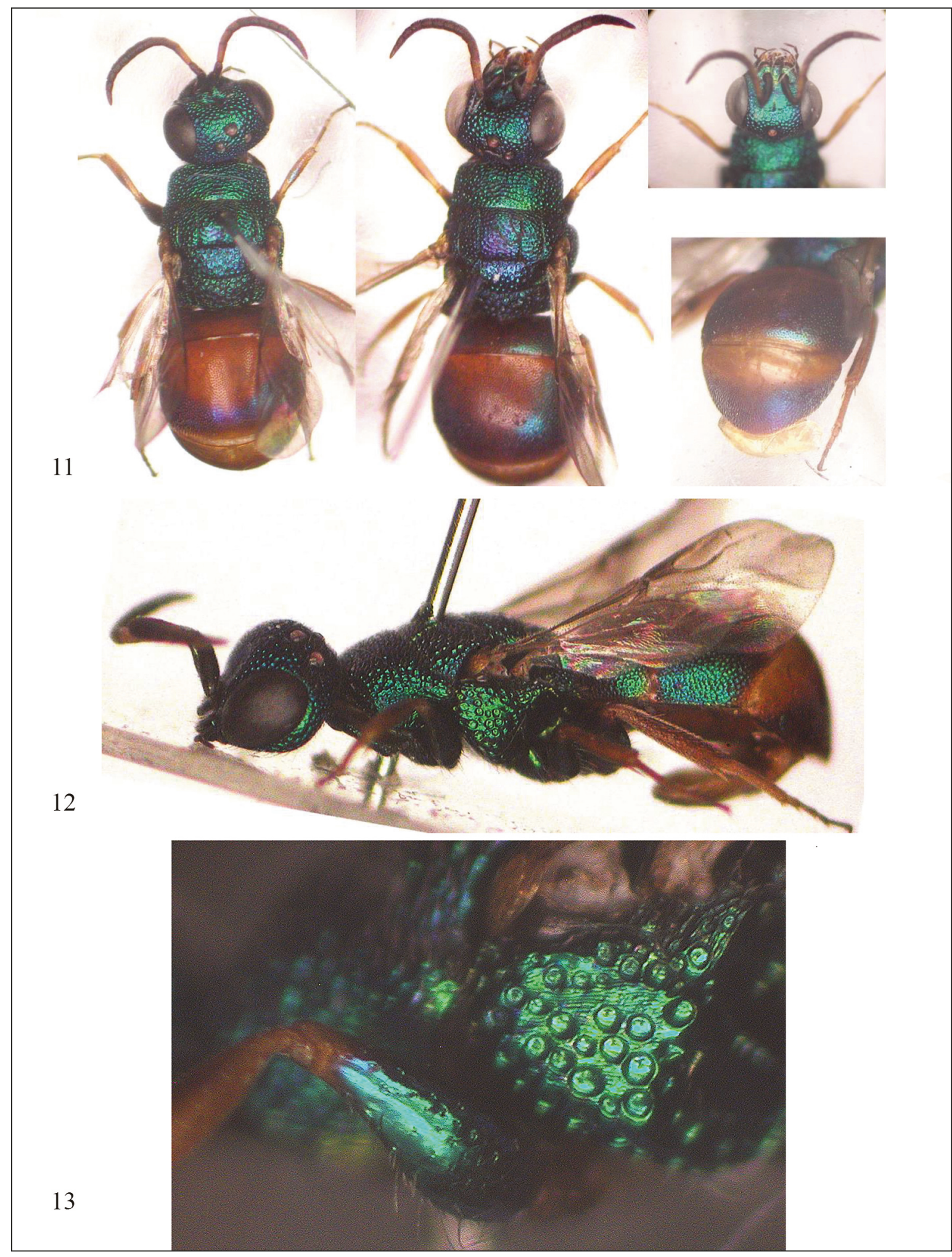

Figure 11. Hedychridium caerulescens n. sp.; left: dorsal view of female type; middle: dorsal view of male paratype; right top: face of male paratype; right bottom: posterior side view of male paratype metasoma. Figure 12. Hedychridium caerulescens n. sp.; lateral view of female type. Figure 13. Detail of left mesopleuron and fore femur of female paratype of Hedychridium caerulescens $\mathrm{n}$. sp. 
Distribution. Egypt, Mali, Morocco, Saudi Arabia, UAE (Strumia, 2014).

Hedychridium holopygum Linsenmaier, 1994

Examined material. Al Wathba Wetland Reserve, 01-28.02.2015, 3 females; same locality, 0131.03.2015, 2 males; same locality, 01-31.01.2015, 1 female.

Distribution. Qatar, UAE (Strumia, 2014).

Hedychridium iridirufum Linsenmaier, 1994

EXAMINED MATERIAL. Al Wathba Wetland Reserve, 19.09-31.10.2015, 2 males, 1 female; same locality, 01-31.07.2015, 5 males, 8 females; Houbara Protected Area, 01-30.06.2016, 4 females.

Distribution. Qatar, Oman, UAE (Linsenmaier, 1994; Strumia, 2008).

Hedychridium planifrons Du Buysson, 1900

EXAMINED MATERIAL. Al Wathba Wetland Reserve, 01-31.03.2015, 1 female.

Distribution. Morocco, Egypt, Palestine, Syria, Oman, UAE (Linsenmaier, 1994).

Genus Hedychrum Latreille, 1802

Hedychrum alfierii Trautmann, 1926

Examined material. Houbara Protected Area, 01-30.06.2016, 1 male.

Distribution. North Africa, Egypt, Palestine, Oman, Saudi Arabia, UAE, Yemen (Strumia, 2014)

Genus Holopyga Dahlbom, 1845.

Holopyga beaumonti Balthasar, 1953

EXAMINED MATERIAL. Al Wathba Wetland Reserve, 01-28.02.2015, 5 males, 2 females; same locality, 01-31.03.2015, 1 male; same locality, 01-31.01.2015, 1 female.

Distribution. Iran, Palestine, Saudi Arabia, UAE and Yemen (Strumia et al., 2016).

REMARKS. Linsenmaier (1994) erroneously con- sidered $H$. beaumonti to be a synonym of $H$. colonialis Mocsáry, 1912. This synonymy is wrong because $H$. colonialis does not belong to the genus Holopyga but to the genus Haba Semenov, 1954 (Strumia, 2016).

Holopyga subglabrata Linsenmaier, 1994

EXAMINED MATERIAL. Al Wathba Wetland Reserve, 01-31.01.2015, 1 male, 1 female.

Distribution. Saudi Arabia, Oman, UAE, Yemen (Linsenmaier 1994, Strumia, 2014).

Holopyga vicissituda Linsenmaier, 1994

Material STUdied. Al Wathba Wetland Reserve, 01-31.01.2015, 1 male, 1 female.

Distribution. Iran, Saudi Arabia, Oman, UAE (Linsenmaier, 1994).

Genus Omalus Panzer, 1801

Omalus margianus (Semenov, 1932)

EXAMINED MATERIAL. Al Wathba Wetland Reserve, 04.04.2017, 6 females; same locality, 20.04.2017, 3 females; same locality, 01-31.01.2015, 2 males, 5 females; same locality, 01-28.02.2015, 2 males, 3 females; same locality, 01-31.03.2015, 2 males; same locality, 01-30.04.2015, 1 female; Houbara Protected Area, 01-31.03. 2016, 2 females.

Distribution. Iran, Turkmenistan, Uzbekistan (Farhad et al., 2018).

Genus Platycelia Dahlbom, 1845

Platycelia ehrenbergi Dahlbom 1845

EXAMINED MATERIAL. Al Wathba Wetland Reserve, 01-30.04.2015, 1 female.

Distribution. Algeria, Tunisia, Libya, Morocco, UAE (Linsenmaier, 1999).

Genus Spintharina Semenov, 1892

Spintharina dubai Bohart 1987

EXAMINED MATERIAL. Al Wathba Wetland Re- 
serve, 01-30.04.2015, 1 male; same locality, 0130.05.2016, 1 male.

Distribution. Iran, Oman, Saudi Arabia, UAE, and Yemen (Linsenmaier, 1994; Strumia, 2008, 2014).

Spintharina integerrima (Klug, 1845)

EXAmined MATERIAL. Al Ramlah Protected Area, 08.11.2018, 2 females.

Distribution. NW-Africa, Palestine, Oman, Saudi Arabia, Sudan, UAE, Yemen.

\section{RESULTS}

About 150 individuals of Chrysididae were captured mainly by the Malaise traps with a total of 24 species (Tab. I). Five species resulted to be new records for UAE, namely: Adelopyga huberi Kimsey, 1988, Hedychridium caerulescens n. sp., Chrysis houbaraeensis n. sp., Chrysis blanchardi Lucas, 1849, and Cephaloparnops denticulatus Spinola, 1838.
The Al Wathba Wetland Reserve has a notable larger richness (17 species, about $36 \%$ of known UAE Chrysididae) with respect to the Houbara Protected Area (11 species). This result confirms the larger biodiversity preserved into humid zones, as was recently observed in a Mediterranean biotope (Strumia et al., 2017).

The two Protected Areas share only five species (all widespread species of the Arabian Peninsula, Table 1). Two interesting and uncommon species were observed only in the Al Wathba Wetland Reserve: Adelopyga huberi Kimsey, 1988 (new record for UAE) and Cephaloparnops denticulatus Spinola 1838 (new record for UAE). Five species were captured only in the Houbara Protected Area and are probably species better adapted to dry biotopes.

Our results confirm the notable richness of genus Hedychridium in Arabian region (Hedychridium caerulescens n. sp.).

\section{Phenology in Abu Dhabi}

The material captured was collected with a monthly timing: only the captures of November

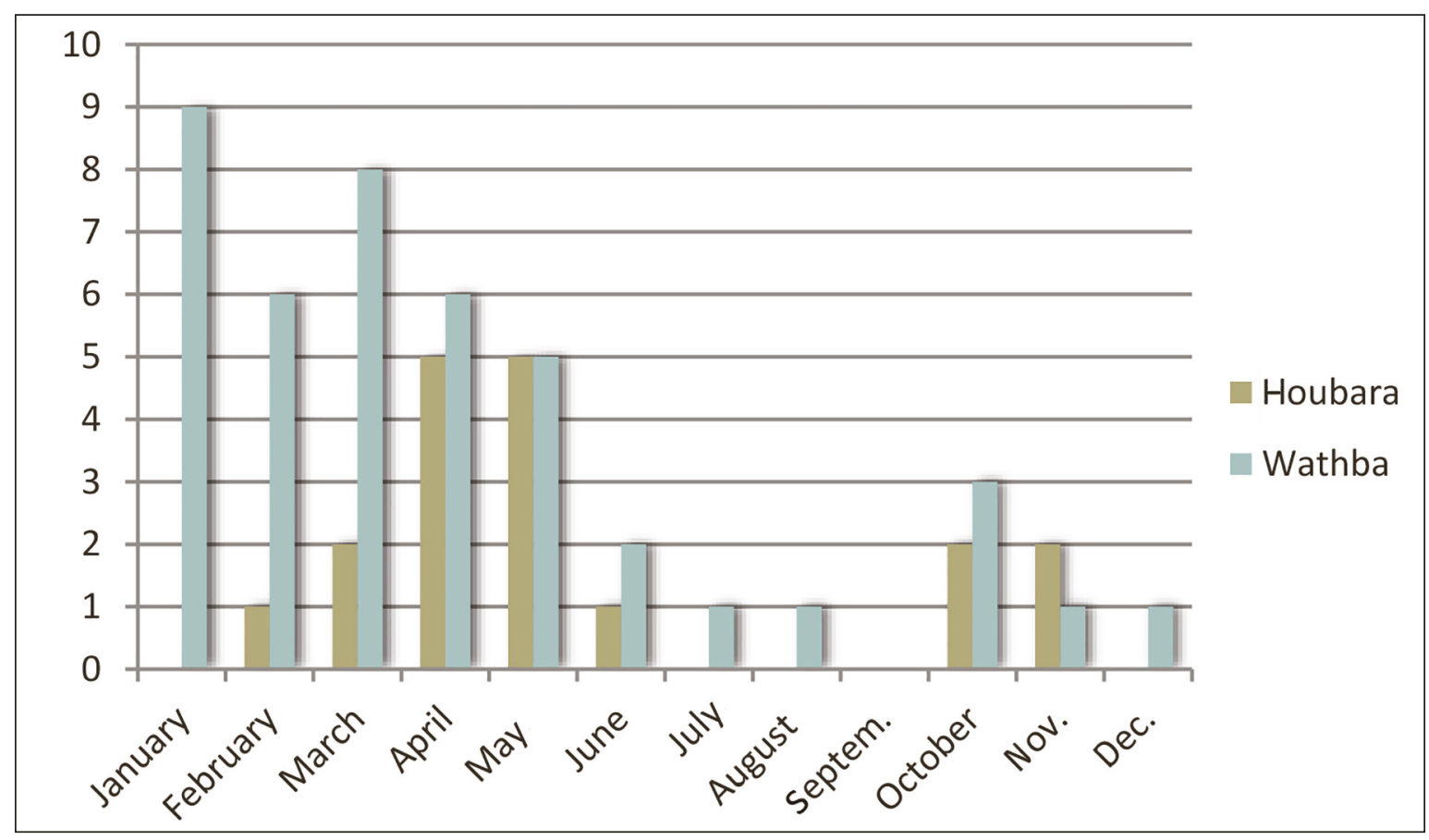

Figure 14. Number of Chrysididae species captured each month in the "Al Wathba" and "Houbara" reserves, respectively. 
and December were cumulated. The monthly number of species reveals an interesting and noteworthy different phenology between the two reserves as shown in figure 14. In Al Wathba the largest number of species is observed in early spring followed by a large decrease in summer and autumn. On the contrary in Houbara the maximum species richness is observed between March and June and in November-December. The availability of meteorological data could suggests an interpretation of this data and possible correlations that need to be confirmed by further observations. The phenology of Al Wathba appears to be correlated with the rainfall distribution in UAE. The influence of humid zone allows species presence in larger number and around all the year.

\section{ACKNOWLEDGEMENTS}

The authors are grateful to Pier Scaramozzino of Pisa University for providing high quality photographic pictures of Adelopyga and Hedychridium, and for useful comments.

\section{REFERENCES}

Farhad A., Rosa P. \& Asghar Talebi A., 2018. Additions to the fauna of Iranian Elampini (Hymenoptera: Chrysididae, Chrysidinae), with key to species and taxonomic notes. Journal of Crop Protection, 7: 191206.

Kimsey L.S., 1988. An unusual new genus of Chrysididae from Oman (Hymenoptera). Psyche 94: 333-335. https://doi.org/10.1155 / 1987/13971

Kimsey L.S. \& Bohart R.M., 1991 [1990]. The Chrysidid wasps of the world. Oxford Science Publications, Oxford, New York, Toronto, $652 \mathrm{pp}$.

Linsenmaier W., 1994. The Chrysididae (Insecta: Hymenoptera) of the Arabian Peninsula. Fauna of Saudi Arabia, 14: 145-206.
Linsenmaier W,. 1999. Die Golwespen Nordafrikas. Entomofauna, Suppl. 10: 1-281

Madl M. \& Rosa P., 2012. A Catalogue of the Chrysididae (Hymenoptera: Chrysidoidea) of the Ethiopian Region excluding Malagasy Subregion. Linzer Biologische Beiträge, 44: 5-169.

Radoszkowski O., 1889. Revision des armures copulatrices des males de la tribu des Chrysidides. Horae Societatis entomologicae rossicae, 23: 3-40.

Rosa P. \& Zai-fu Xu, 2015. Annotated type catalogue of the Chrysididae (Insecta, Hymenoptera) deposited in the collection of Maximilian Spinola (1780-1857), Turin Zookeyes, 31: 1-96. https://doi.org/10.3897/ zookeys.471.6558

Rosa P., 2017. Review of the Palaearctic species of the genus Colpopyga (Hymenoptera: Chrysididae) with description of a new species. Zoosystematica Rossica, 26: 294-306. https://doi.org/ 10.31610/zsr/ 2017.26.2.294

Strumia F. \& Dawah H., 2008. Contribution to the knowledge of the Chrysididae of Saudi Arabia (Hymenoptera, Chrysididae). Frustula Entomologica, 31 : $1-96$.

Strumia F., 2008. Order Hymenoptera, family Chrysididae. In: "Arthropod fauna of the UAE", (ed. A. van Harten), Volume 1: 375-387. Dar Al Ummah Printing, Abu Dhabi. 754 pp.

Strumia F., 2014. Upgraded checklist of the Chrysididae from the UAE. In: "Arthropod fauna of UAE", (ed. A. van Harten), Vol. 5: 471-504. Department of the President's Affairs, Abu Dhabi, United Arab Emirates, $744 \mathrm{pp}$.

Strumia F., 2016. Review of the genus Haba Semenov, 1954 (Hymenoptera: Chrysididae) with the key to species. Zootaxa, 4116: 289-294. https:// doi.org /10.11646/ zootaxa.4161.2.11

Strumia F., Fallahzadeh M., Izadi E. \& Tavassoli H., 2016. Addition to the tribe Elampini (Hymenoptera Chrysididae) of southern Iran, with description of a new subspecies. Trends in Entomology, 12: 51-61.

Strumia F., Gianasso D., Filippi L., Massa B. \& Pagliano G., 2017. Influence of a humid zone on entomocenosis diversity. Il Naturalista siciliano, 41: 12-144. 